\title{
Annual changes in a bird assembly on artificial perches: Implications for ecological restoration in a subtropical agroecosystem
}

\author{
Huilquer Francisco Vogel ${ }^{1,5}$, Erica Spotswood ${ }^{2}$,João Batista Campos ${ }^{3}$ \& Fernando Campanhã Bechara ${ }^{2,4}$ \\ ${ }^{1}$ Universidade Estadual do Paraná, Ciências Biológicas, União da Vitória, PR, Brazil. \\ ${ }^{2}$ University of California, Department of Environmental Science, Policy and Management, Berkeley, USA. \\ ${ }^{3}$ Secretaria de Estado de Meio Ambiente e Recursos Hídricos do Paraná, Coordenadoria de Biodiversidade \\ e Florestas, Curitiba, PR, Brazil. \\ ${ }^{4}$ Universidade Tecnológica Federal do Paraná, Engenharia Florestal, Dois Vizinhos, PR, Brazil. \\ ${ }^{5}$ Corresponding author: Huilquer FranciscoVogel, e-mail: huilquer@unespar.edu.br,huilquer@hotmail.com
}

VOGEL, H.F., SPOTSWOOD E., CAMPOS, J.B., BECHARA, F.C. Annual changes in a bird assembly on artificial perches: Implications for ecological restoration in a subtropical agroecosystem. Biota Neotropica. 16(1): e0069. http://dx.doi.org/10.1590/1676-0611-BN-2015-0069

\begin{abstract}
Artificial perches are used in tropical forest restoration projects to increase the dispersal of seeds into restored areas. The ability of perches to enhance seed deposition depends on their ability to attract seed dispersing birds, as well as the correlation between the season of bird visits to perches and the phenology of fruit production in adjacent forests. Using data collected from a large-scale restoration project, we characterized the community of birds that utilize artificial perches over the course of one year. We hypothesized that the structure of a bird assemblage that uses artificial perches is affected by seasonal variation. We aimed to describe the richness, abundance and diversity of a bird assemblage on artificial perches in a subtropical Atlantic forest restoration experiment in Southern Brazil. Richness and abundance estimates of the avian fauna were obtained from eight artificial perches placed in four experimental plots ( $\sim 2 \mathrm{y}$-old). Parameters of richness and abundance were compared using ANOVA. The bird assemblage was described using SHE analysis [richness (S), diversity $\left(\mathrm{H}^{\prime}\right)$ and evenness $(\mathrm{E})$ ], with additional estimates of occurrence and dominance. In total, 451 records of $32 \pm$ 3.16 SD species were obtained. Thraupidae was the most numerous family (nine species, $28.12 \%$ of the total). Richness and abundance varied seasonally and were highest during spring and summer. Five migratory species of flycatchers were recorded between spring and early autumn. Perches were ineffective in attracting specialized frugivorous birds, emphasizing that seed dispersal tends to be carried out primarily by generalist omnivores in the initial phase of forest regeneration.
\end{abstract}

Keywords: Avian fauna, ecological restoration, Atlantic forest, nucleation.

VOGEL, H.F., SPOTSWOOD E., CAMPOS, J.B., BECHARA, F.C. Variação anual na assembleia de aves em poleiros artificiais: Implicações para a restauração ecológica em agroecossistema subtropical. Biota Neotropica. 16(1): e0069. http://dx.doi.org/10.1590/1676-0611-BN-2015-0069

Resumo: Poleiros artificiais são usados em projetos de restauração de florestas tropicais para aumentar a dispersão de sementes em áreas restauradas. A capacidade de poleiros para melhorar a deposição de sementes depende da sua capacidade de atrair aves dispersoras, bem como a correspondência entre a estação de visitas de aves nos poleiros e a fenologia da produção de frutos nas florestas adjacentes. Usando dados coletados a partir de um projeto de restauração de grande escala, que caracterizaram a comunidade de aves que utilizam poleiros artificiais ao longo de um ano, foi testada a hipótese que a estrutura da assembleia de aves em poleiros artificiais é afetada por variações sazonais. O objetivo foi descrever a riqueza, abundância e diversidade da assembleia de aves que visitam poleiros artificiais em um experimento de restauração florestal da mata Atlântica subtropical no sul do Brasil. Estimativas de riqueza e abundância da avifauna foram obtidas de oito poleiros artificiais colocados em quatro parcelas experimentais ( $\sim 2$ anos de idade). Parâmetros de riqueza e abundância foram comparados usando ANOVA. A assembleia de aves foi descrita por meio de análise SHE [riqueza (S), diversidade (H') e equitabilidade (E)], com estimativas adicionais de ocorrência e dominância. No total, foram obtidos 451 registos de $32 \pm 3,16$ DP espécies. Thraupidae foi a família mais abundante (nove espécies, 28.12\% do total). Riqueza e abundância variaram sazonalmente, sendo mais elevadas durante a primavera e verão. Foram registradas cinco espécies migratórias de tiranídeos entre a primavera e o início do outono. Poleiros foram ineficazes na atração de aves frugívoras especializados, enfatizando que a dispersão de sementes tende a ser realizada principalmente por onívoros generalistas na fase inicial de regeneração florestal.

Palavras-chave: Avifauna, restauração ecológica, Mata Atlântica, nucleação. 


\section{Introduction}

In diverse tropical forests, restoration has emerged as a tool for promoting the recovery of forests after deforestation and agricultural abandonment (Reis et al. 2010). However, recovery in diverse tropical forests can be notoriously slow (Rey-Benayas et al. 2008). The use of bird perches within restoration projects can aid the recovery process by increasing the dispersal of forest seeds into restored areas (Shiels \& Walker 2003), the connectivity between forest remnants and the genetic variability of degraded habitats (Wuderle Jr. 1997, Holl 1998). In addition to seed dispersal, perches may also increase the diversity of avian fauna from non-seed dispersal guilds, which could assist with the recovery of other ecosystem functions (Bocchese et al. 2008). Moreover, artificial perches can complement other common techniques such as the high-diversity planting of trees (Rodrigues et al. 2011, Carnevale \& Montagnini 2002), assisted regeneration (Shono et al. 2007) and nucleation (Reis et al. 2010, Corbin \& Holl 2012).

Quantifying the use of artificial perches is a critical first step in understanding how perches affect avifaunal diversity and ecosystem function in restored areas. For example, in some tropical areas dominated by exotic invasive grasses, perches have not been effective at increasing the recruitment of primary forest seeds in restored areas (Holl et al. 2000, César et al. 2014). However, perches may serve other functions, including furnishing hunting and resting areas for raptorial species, which may act in the population control of granivorous and herbivorous animals such as insects and rodents (Hall et al. 1981, Pias et al. 2012). They may also attract pollinator (Shiels \& Walker 2003, Lindell \& Thurston 2013), generalist insectivorous and omnivorous birds (Bocchese et al. 2008, Morrison \& Lindell 2012). These trophic groups may act as occasional dispersers of forest fruit, thus substituting some of the ecosystem functions performed by specialized frugivorous birds, which are generally rare or absent in degraded environments (Sekercioglu 2006, Pizo 2007).

Dispersal into restored areas may not occur either because frugivores may be absent (Staggemeier \& Galetti 2007, Caves et al. 2013), or because the seasonality of perch use does not match the seasonality of fruit production. Furthermore, in some subtropical regions, there is evidence that many birds contribute only seasonally to seed dispersal. Thus, seasonal matching between perch use by dispersers and the phenological cycle of vegetation is key to the effectiveness of perches in promoting the dispersal of forest seeds (Zanini \& Ganade 2005). Little attention has been given to the relationship between annual variation in the deposition of seeds and the resulting changes in the composition of the bird assemblage (Vicente et al. 2010, Hartz et al. 2012). For example, one-third of the austral migrants are the Tyrannidae family (Chesser 1994, Alves 2007) and their strong preference for perches (Holl et al. 1998, Vicente et al. 2010) and migratory behavior could be reflected in the seasonal changes in the use of artificial perches. Moreover, most studies involving birds on artificial perches provide little emphasis on quantitative parameters of the avian fauna.

Here, we characterize an avifaunal assembly that uses artificial perches within a large-scale restoration experiment that uses nucleation techniques to accelerate restoration in a subtropical agroecosystem (Reis et al. 2010). Using data collected over two years through multiple seasons, we estimate richness, abundance and diversity of species using perches. To understand what ecosystem functions may be provided by birds using perches, we also identify the trophic position and dominance of all species. We ask whether the avian community changes throughout the year and whether annual migration patterns affect how perches are used. Lastly, we ask whether seasonal changes in seed-dispersing species match the seasonal production of forest fruit. We expected higher richness and abundance of birds using perches in the spring and summer, when most austral migrants occur in Southern Brazil (Belton 1985, Stotz et al. 1996, Ridgely \& Tudor 2001).

\section{Materials and Methods}

\section{Study area}

This study was developed on a research farm of the Federal Technological University of Paraná (Universidade Tecnológica Federal do Paraná; 2541'43.35"S; 536'12.27”W) in the municipality of Dois Vizinhos (Paraná state, Southern Brazil; Figure 1). The area is approximately $50 \mathrm{~m}$ from a stream, 495-504 $\mathrm{m}$ above sea level. Climate in the region is $\mathrm{Cfa}$, according to Köppen, with a mean temperature of $19.2^{\circ} \mathrm{C}$ and annual frost (Maack 2002). Precipitation is 2,044 $\mathrm{mm} /$ year, with no hydric deficit. Vegetation is classified as Atlantic subtropical forest in an ecotone between Araucaria moist forest and seasonal semideciduous forest. The experimental area was historically used for agriculture and pasture until October 2010, when a restoration experiment began. Four randomized plots were established at a distance of $\sim 13 \mathrm{~m}$ from one another using a set of nucleation techniques (see next item).

\section{Nucleation techniques}

Four out of twelve batches $(40$ x $54 \mathrm{~m})$ were randomly selected for implementation of the nucleation techniques (Figure 1). A set of seven nucleation techniques was used in each plot (developed and implanted by F.C. Bechara in an adaption from Reis et al. 2010) in six $3 \times 40 \mathrm{~m}$ strips, occupying $1 / 3$ of the plot (2/3 have no intervention to promote natural regeneration). The seven techniques were: (1) six artificial shelters for the fauna (1 m x $1 \mathrm{~m} \times 1 \mathrm{~m}$ pile of firewood); (2) two tripods: artificial perches made from the trunk plus the dry crown of eucalyptus trees $(10 \mathrm{~m}$ high and a diameter of 15 to $20 \mathrm{~cm}$ at soil level). The sweet passion fruit (Passiflora alata Curtis), native to the region, was cultivated on the perches; (3) transfer of topsoil seed bank (collected in a conserved forest remnant) in six 1- $\mathrm{m}^{2}$ nuclei; (4) seed rain (captured in 30 seed traps for 12 months in a conserved forest remnant) in six 1-m² nuclei; (5) nuclei of cover crop composed of pigeon pea (Cajanus cajan (L.) Millsp.; Fabaceae) in $123 \times 4 \mathrm{~m}$ nuclei; (6) islets of native trees (Anderson, 1953) composed of five seedlings spaced $1 \mathrm{~m}$ apart and arranged in a "+" shape, with four seedlings of the same rapid-growth pioneer species at the edges and one non-pioneer species in the center (we used 12 pioneer species and 24 non-pioneer species in a density of 24 islets); (7) islets of terrestrial epiphytes composed of five bromeliad (Bromelia antiacantha Bertol) saplings spaced $0.5 \mathrm{~m}$ apart in a "+" shape (Anderson, 1953).

\section{Data collection}

A census of the birds was undertaken from January to December 2012 (in the second year after the start of restoration). Richness and abundance was obtained by direct counting (Bibby et al. 2000) at a single site in the center of each experimental plot between the two perches (Figure 1 in the 

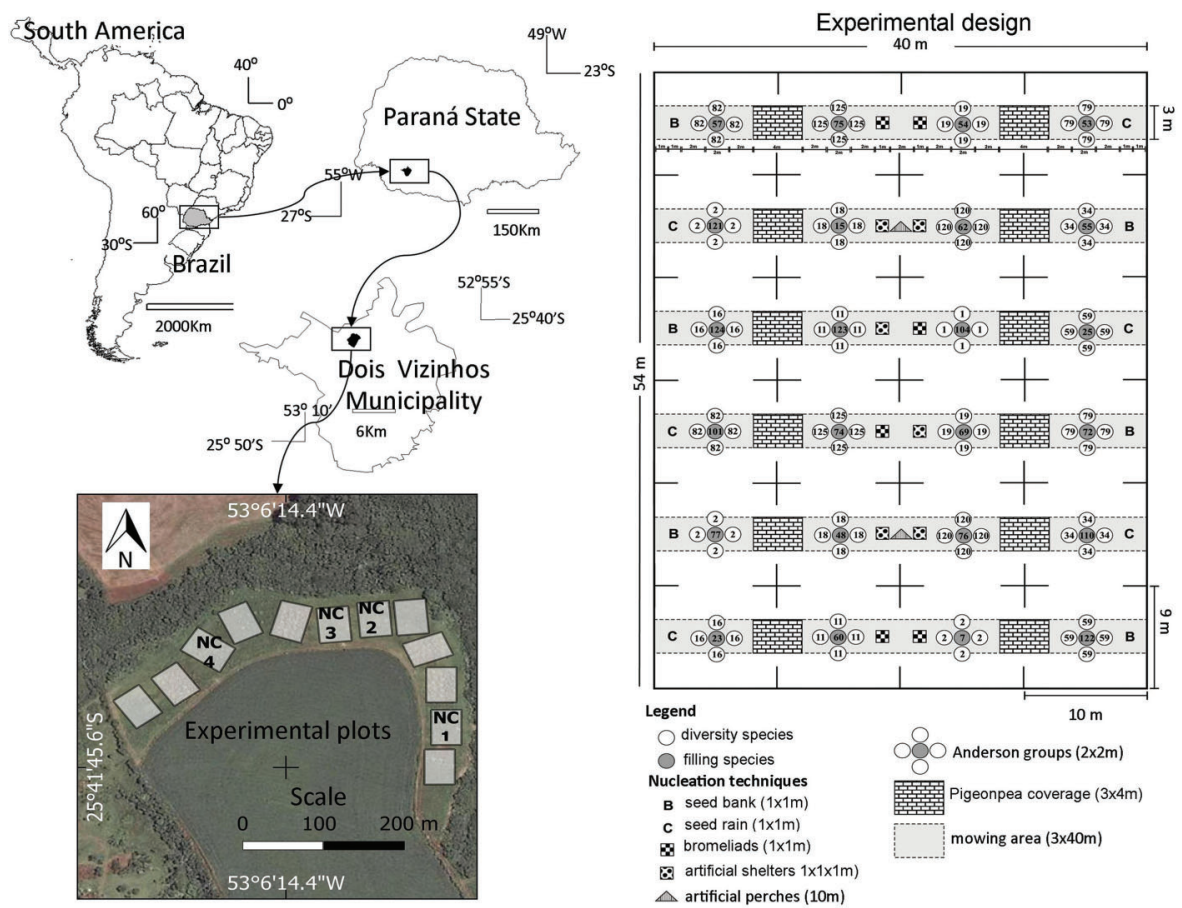

Figure 1. Area of study and distribution of the experimental plots. In detail, experimental design containing nucleation techniques. In the experiment there are twelve experimental plots but only four ( $\mathrm{NC} 1,2,3 \& 4)$ were restored by nucleation techniques.

experimental design). Sampling took place twice a month on two successive days of observation. Two 10-minute point counts (separated by about eight hours) were conducted each day in the morning $\sim 06 \mathrm{~h} 40$ to $\sim 08 \mathrm{~h} 40-3 \mathrm{GMT}$ and in the afternoon $\sim 16 \mathrm{~h} 30$ to $\sim 18 \mathrm{~h} 30$. The plot at the start of sampling was chosen at random, and the sequence was always from the first to the last plot. Six counts were conducted at each site per season, for a total of 24 counts per site, with a sampling effort of $8 \mathrm{~h}$ per plot or $32 \mathrm{~h}$ of total effort. Only individuals specifically resting on perches were recorded and the nomenclature used to identify the birds was taken from the Brazilian Committee of Ornithological Records (CBRO 2014).

\section{Statistical analyses}

In order to describe the diversity of the bird assemblage that used the perches, richness estimates were obtained using rarefaction with the estimators Jackknife 1 and Bootstrap (10,000 randomizations). Rarefaction estimates both the true diversity of a system and the sampling effort required to obtain a reasonable approximation of species diversity. The technique is appropriate when the true diversity of a system is unknown, and when the sampled populations are composed of several unidentified subpopulations (Colwell et al. 2004). Diversity was estimated using SHE analysis (Buzas \& Hayek 1998), which examines the relationship between $\mathrm{S}$ (species richness), $\mathrm{H}^{\prime}$ (Shannon-Wiener diversity index) and LnE (evenness, measure using the Pielou index $-\mathbf{J}$ '). This approach is an alternative to evaluating general tendencies of the parameters that compose diversity over the increase in the sampling effort. Exponential function for the species accumulation curve and linear functions ( $\mathrm{Ln}$ ) of evenness and diversity were also obtained.

Species abundance was interpreted based on Berger-Parker - D dominance (Krebs 1999, Melo 2008). Dominance classes were later grouped according to Palissa et al. (1977): eudominant ( $>10 \%)$; dominant $(10 \vdash 5 \%)$; subdominant $(2+5 \%)$; recessive $(1 \vdash 2 \%)$, rare $(<1 \%)$. We obtained the frequency of occurrence index (Linsdale \& Rodgers 1937), expressed by the number of samples in which the species was present in relation to the sampling total. Categories used to form the frequency of occurrence classes were based on Dajoz (1983): constant (> 50\%); accessory ( $25 \%$ to $50 \%)$; accidental $(<25 \%)$. The indices of dominance $(\%)$ and frequency $(\%)$ were related through a linear regression analysis $\left(\mathrm{PAST}^{\mathrm{B}}\right.$ ver. 2.17; Hammer et al. 2001), where dominance acts as a dependent variable, with the objective of verifying if it could predict perch use occurrence parameters.

In order to quantify the trophic position of birds using artificial perches, we used the guild proposed by Almeida et al. (2003). Each species was categorized as either a migrant (M) or a resident (R), based on Bencke (2001). The proportions of species categorized by dominance, frequency of occurrence, trophic categories and status of occurrence were compared using a chi-square test, with $\alpha=0.05$ statistical acceptance. To compare bird community composition between seasons, we used detrended correspondence analysis (DCA), with greater weight given to low-abundance species, enabling the obtainment of Pearson correlation measurements between species and axes (PC-ORD ${ }^{\mathrm{TM}}$ ver. 6; McCune \& Mefford 2011). Mean scores of the axes between seasons were later tested through Kruskal-Wallis non-parametric variance analysis (PAST $^{\mathbb{R}}$ ver.2.17; Hammer et al. 2001).

In order to quantify how seasonal variation in the use of perches could affect the dispersal of seeds under perches, birds were evaluated based on their known dispersal capacity from the literature. Each species was either a probable disperser (P-dispersers), or a likely non-disperser (N-dispersers), based on Pineschi (1990), Pizo (2004), Fonseca \& Antunes (2007) and Athiê \& Dias (2012). Disperser categories were used to evaluate 

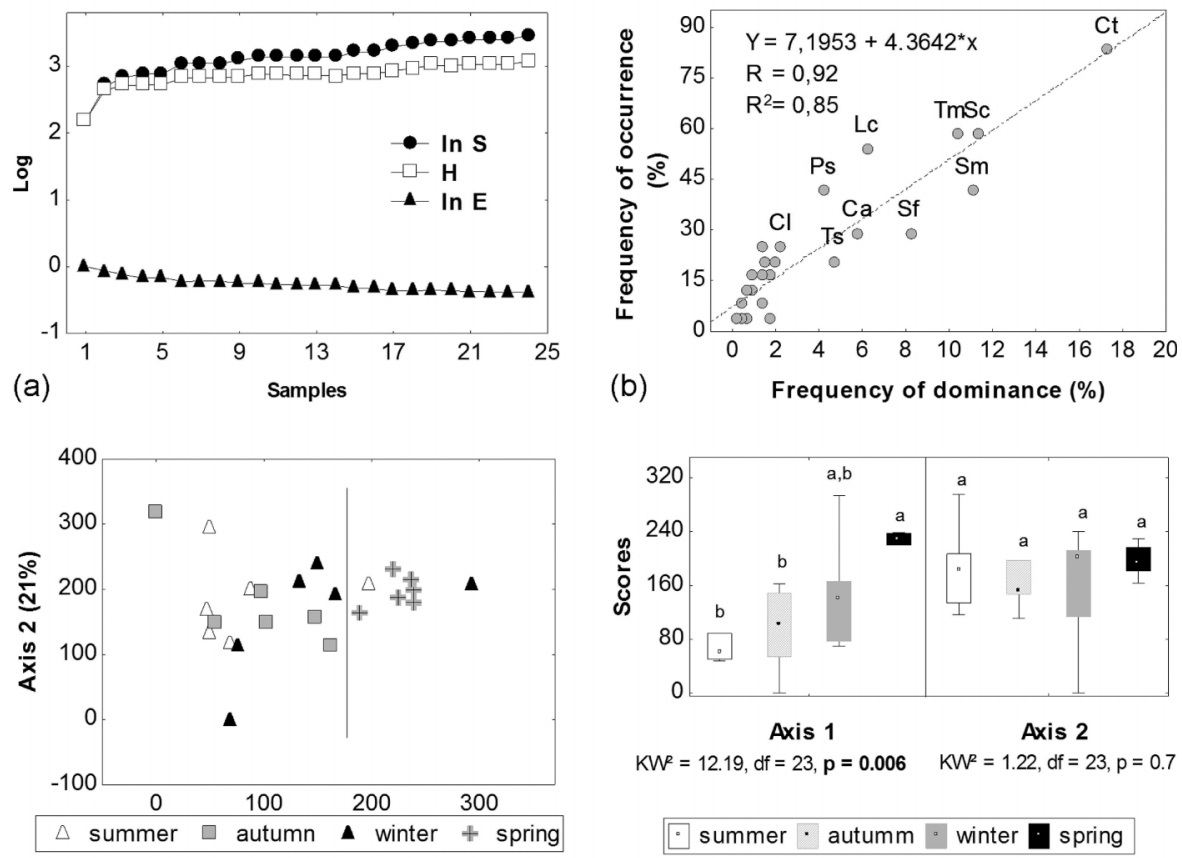

(c)

Axis $1(39 \%)$

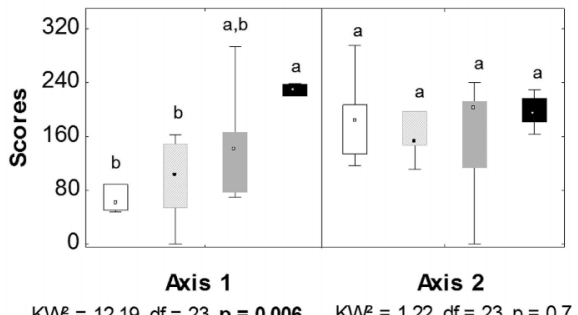

$\mathrm{KW}^{2}=12.19, \mathrm{df}=23, \mathrm{p}=\mathbf{0 . 0 0 6} \quad \mathrm{KW}^{2}=1.22, \mathrm{df}=23, \mathrm{p}=0.7$

$$
\text { summer } \cdot \text { autumm } * \text { winter } \cdot \text { spring }
$$

(d)
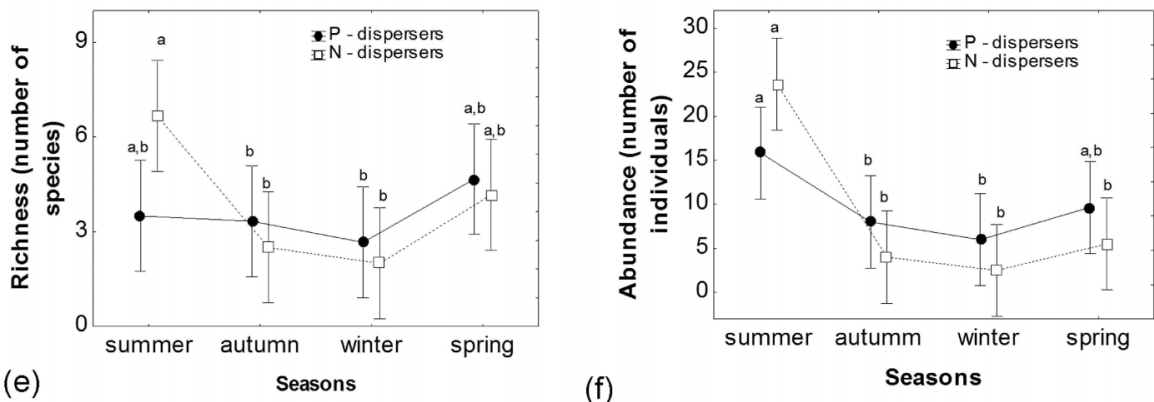

Figure 2. (a) Analysis of species richness (S), diversity (H') and Evenness (E) of birds using perches across all seasons; (b) Regression analysis between the frequency of dominance and the frequency of occurrence of birds that use artificial perches. The codes represent: $(\mathrm{Ct})$ Columbina talpacoti, (Sc) Sporophila caerulescens, (Tm) Tyrannus melancholicus, (Sm) Sporagra magellanica, (Lc) Lanio cucullatus, (Sf) Sicalis flaveola, (Ps) Pitangus sulphuratus, (Ca) Crotophaga ani, (Ts) Tyrannus savanna and (Cl) Chlorostibon lucidus. The letters represent the genera and species, respectively; (c) Detrended Correspondence Analysis (DCA); (d) DCA with respective Kruskal-Wallis test for scores of axes; (e) Richness test; (f) Abundance of potential disperser species that used artificial perches (ANOVA; where the means followed by the same letters do not differ by means of the Tukey test, with minimum acceptance of $\mathrm{P}<0.05$ ).

how the abundance and richness of likely disperser and nondisperser birds varied between seasons by the comparing seasonal richness and abundance in each category, using analysis of variance [factorial ANOVA (two groups $v s$. four seasons)]. The Bartlett and the Shapiro-Wilk tests were used to check the homogeneity of the variances and normality of the data, respectively (Quinn \& Keough 2002).

\section{Results}

A total of 451 records of $32 \pm 3.16$ species belonging to 14 families (Appendix 1) were obtained using the following richness estimates: $48.11 \pm 6.17$ (Jackknife 1) and $30.49 \pm$ 2.63 (Bootstrap). Thraupidae was the most numerous family, with nine species represented $(28.12 \%)$, followed by Tyrannidae ( $n=6$ or $18 \%$ ). The species accumulation curve obeyed the logarithmic model expressed by the function $\mathrm{y}=8.2793$ $\ln (x)+5.2989$ and $\mathrm{R}^{2}=0.997$. The linear models obtained from evenness $\left(\mathrm{y}=-0.0141 x-0.0881 ; \mathrm{R}^{2}=0.8964\right)$ and diversity $\left(\mathrm{y}=0.0213 x+2.5905 ; \mathrm{R}^{2}=0.699\right)$ show a tendency of decrease in evenness, contrary to the increase in diversity.

There were relatively few dominant species, and most species were rarely seen on perches. Dominance categories were not evenly distributed $\left(\chi^{2}=13.93\right.$, df $\left.=4 ; P=0.007\right)$, with a predominance of rare species $(n=14 ; 43.75 \%)$, followed by recessive species (25\%). Only Columbina talpacoti, Sporophila caerulescens, Sporagra magellanica and Tyrannus melancholicus were eudominant. Species occurrence analysis showed that only four (12.5\%) species (C. talpacoti, Lanio cucullatus, S. caerulescens and T. melancholicus) were constant on the artificial perches. Most species fell into the accidental category $\left(n=24 ; 75 \% ; \chi^{2}=25\right.$, $\mathrm{df}=3 ; P<0.001)$. Regression analysis allows the diagnosis that the frequency of dominance can predict the frequency of occurrence $\left(\mathrm{y}=7.1955+4.3642^{*} x\right)$, with adjusted $\mathrm{R}^{2}=0.85$ (Figure $2 \mathrm{~b}$ ).

Five trophic groups represented the species visiting perches, most of which were granivorous $\left(n=11 ; 34.37 \% ; \chi^{2}=13.31\right.$, 
$\mathrm{df}=4 ; P<0.05)$, omnivorous $(n=10)$, insectivorous $(n=8)$ or carnivorous $(n=2)$. Only a single nectarivorous species (Chlorostilbon lucidus) was found, and no exclusively frugivorous birds were seen. DCA (Figure 2c) separated the bird assemblage between spring, and autumn and summer (Figure 2d). In general, the species were weakly correlated with the first two retained axes, which together explained $60 \%$ of the variance (Appendix 1).

Seasonal variation in both richness $\left(F_{[3.40]}=14.79 ; P<0.01\right)$ and abundance $\left(F_{[3.40]}=4.33 ; P=0.01\right.$; Table 1 and Figure $2 \mathrm{e}$ and $f$ ) was significant, supporting our hypothesis of finding greater species richness and abundance in spring and summer. There was no effect of seasonality on the groups or interaction of the factors. However, a Tukey HSD test showed that the richness of the $\mathrm{N}$-disperser group was higher only during summer $(6.66 \pm 1.96$ SD species); whereas the abundance of individuals was higher in summer for both groups (P-dispersers 15.83 \pm 5.11 SD and $\mathrm{N}$-dispersers $23.66 \pm$ 12.58 SD; Figure $2 \mathrm{e}$ and $\mathrm{f}$ ).

\section{Discussion}

We found that artificial perches were used by a diverse assemblage of species occupying different trophic positions. Birds that used perches are capable of performing a number of ecosystem functions, including reducing seed predation by rodents (carnivores), and consuming insects (insectivores) and grains (granivores). However, specialist frugivores were absent from perches, and omnivorous species capable of dispersing seeds varied seasonally in richness and abundance. Our main conclusion is that while ecosystem functions may be enhanced by artificial perches, the capacity of perches to increase seed input from adjacent forest may be limited, i.e. dispersal tends to be carried out primarily by generalist omnivores in the initial phase of forest regeneration.

The richness found in this work (32 species) was near what was obtained by the Bootstrap estimator, showing a satisfactory sampling effort. Based on the function of the species accumulation rate, five years of sampling would be necessary to reach the richness estimated by the Jackknife 1 method (48 spp.). However, the branches of the artificial perches began to break after two years, reducing the landing area. This may explain the tendency of a decrease in evenness during sampling, because some aggressive species (e.g. flycatchers) tend to defend landing or territorial sites (Tomaz \& Alves 2009), excluding other species. The gradual increase in diversity $\left(\mathrm{H}^{\prime}\right)$ is due to the arrival of migrant individuals in the spring.

Other studies have found variable numbers of species using artificial perches, with values between seven species in Guedes et al. (1997) and 35 in Bechara et al. (2007). Such variation can be attributed to several factors, including perch type (Silva et al. 2010), structure and degree of habitat and landscape alteration (Staggemeier \& Galetti 2007, Pillatt et al. 2010), and variations in the sampling effort and methodology. Another factor that deserves more attention is the optimum density of perches in the landscape. Few perches can concentrate the birds at a single site; whereas many perches can dilute abundance, giving a false interpretation of efficiency (Silva et al. 2010).

We found that the species that used perches most frequently were also dominant. Among the most abundant species, only T. melancholicus is an effective disperser, ingesting fruits from forest edges and depositing the seeds in open environments (Fonseca \& Antunes 2007, Athiê \& Dias 2012). Other dominant species (including C. talpacoti, L. cucullatus, Zenaida auriculata and Volatinia jacarina) are granivorous and feed on seeds of Poaceae and Asteraceae (Belton 1985, Azpiroz et al. 2012), which are abundant in the area. The presence of granivorous birds on artificial perches is common. These species may occasionally consume fruit and are potential dispersers. However, granivores may also limit seed deposition under perches, due to the predation of seeds already dispersed by other birds (Christianini \& Galetti 2007). The role of birds as dispersers or predators of seeds deserves greater study, because many granivorous birds have been recorded carrying out frugivory and dispersal. Z. auriculata and $V$. jacarina (Vieira \& Silva 1997, Bucher \& Bocco 2009) are examples.

We found a structural change in the bird assemblage visiting perches during the spring, corresponding to the arrival of the first austral migrants (Joseph 1996, Alves 2007). Many species in the Neotropical region contain both migratory and non-migratory individuals (Belton 1985, Sick 1997). Thus, as more migrants return from wintering sites to reproduce, the abundance of certain species can increase during summer. In the DCA of our study, Turdus amaurochalinus it primarily responsible for the spring separating in the axis 1 in relation mostly autumn and winter.

Both migratory and non-migratory individuals were present at our study site during the reproductive season, and this was reflected in an increase in the abundance of this species on perches during the summer (Capllonch et al. 2008, Vogel et al. 2012). T. amaurochalinus is omnivorous (Gasperin \& Pizo 2012) and one of the most important dispersers in agricultural areas or near agroecosystems (Pizo 2004).

Notably, specialized dispersers were never seen using perches in our study. Thus, generalist dispersers, and seasonal variations in their occurrence, are key to understanding the potential for perches to enhance seed dispersal. Other studies

Table 1. Result of the factorial analysis of variance between N-disperser and P-disperser groups. The abbreviations SS, DF, MS, F and P represent the sum of squares, degrees of freedom, mean square, ANOVA test value and statistical significance.

\begin{tabular}{|c|c|c|c|c|c|c|}
\hline & Effect & SS & DF & MS & $\mathbf{F}$ & $\mathbf{P}$ \\
\hline \multirow[t]{4}{*}{ Abundance } & Groups & 11 & 1 & 11 & 0.27 & 0.60 \\
\hline & Seasons & 1782 & 3 & 594 & 14.79 & 0.00 \\
\hline & Interaction & 310 & 3 & 103.30 & 2.57 & 0.06 \\
\hline & Error & 1606.50 & 40 & 40.15 & - & - \\
\hline \multirow[t]{4}{*}{ Richness } & Groups & 1.02 & 1 & 1.02 & 0.22 & 0.63 \\
\hline & Seasons & 58.90 & 3 & 19.63 & 4.33 & 0.01 \\
\hline & Interaction & 33.23 & 3 & 11.08 & 2.44 & 0.07 \\
\hline & Error & 181.16 & 40 & 4.52 & - & - \\
\hline
\end{tabular}


Vogel, H.F. et al.

including perches have also found similar results (e.g. Shiels \& Walker 2003, Pillatt 2010, Vicente et al. 2010). The absence of frugivorous species was probably caused by the defaunation brought about by site degradation (Gomes et al. 2008). Regenerating environments also furnish few food and reproductive resources for specialized frugivores, including cavities for nests and availability of fruits during the whole year (Sekercioglu 2006, Pizo 2007, Pillat et al. 2010).

Five migratory bird species were recorded, all from Tyrannidae (Elaenia flavogaster, Megarynchus pitangua, Tyrannus melancholicus, Tyrannus savanna and Empidonomus varius). This bird group has an insectivorous diet (Ridgely \& Tudor 2001, Gabriel \& Pizo 2005, Martins-Oliveira et al. 2012), which may be useful in the control of forest pests (Strong et al. 2000). Insectivory is likely to be highest during the reproductive period for birds in Southern Brazil, which occurs between spring and autumn (Belton 1985, Sick 1997), when many species require a large quantity of insects to feed their chicks (Argel-de-Oliveira et al. 1998, Marini et al. 2009). A second benefit brought about by the presence of flycatchers on perches is the capacity to promote seed dispersal in pastures and open areas (Fonseca \& Antunes 2007, Gabriel \& Pizo 2005). On the other hand, flycatchers are the main species responsible for mobbing, a behavior that consists of defending territory against other birds (Cunha \& Fontenelle 2014). When flycatchers are present on perches during their reproductive period, they tend to chase away other species that can exercise important ecosystem functions in restoration, including seed dispersal by toucans (Galetti et al. 2000) and the predation of rodents by hawks (Hall et al. 1981, Pias et al. 2012).

For both the seasonal semideciduous forest and the mixed ombrophilous forest (Araucaria moist forest) of Southern Brazil, the greatest availability of fruits occurs between spring and summer (Mikich \& Silva 2001, Liebsch \& Mikich 2009), when our study found the abundance and richness of potential dispersers to be highest. This synchrony between peak fruit availability and peak disperser abundance in this agroecosystem emphasizes the importance of this mutualism (Zanini \& Ganade 2005, Jordano et al. 2006, Carlo et al. 2007, Hartz et al. 2012). In summary, we found seasonal variation in the richness and abundance of the avian fauna using the artificial perches in the early stages of forest regeneration ( $\sim 2$ years of age) within a restoration experiment. Fifty percent of the birds that used the perches (representing five trophic groups) were possible dispersers. The use of perches was ineffective in attracting specialist frugivorous birds, emphasizing that seed dispersal in fragmented landscapes tends to be carried out mainly by generalist omnivores and insectivores, among which migratory or partially migratory species also occur. Seasonal variation in the richness and abundance of birds using perches corresponded to the peak fruiting season for most of the zoochoric species that occurred in the adjacent forest, highlighting the potential for artificial perches to increase seed deposition into restoration areas. Future studies are recommended to evaluate the dispersal capacity of granivores, which were the most frequent and abundant in this study.

\section{Acknowledgments}

We thank CNPq (Conselho de Desenvolvimento Científico Tecnológico) for financing the project (process no. 575081/2008-2) and COPEL-GET, especially Murilo L. Barddal, for the implantation and forest maintenance. We also thank forest technician Gilmar Poser Brizola for help in the field. We are grateful to the Programa em Ecologia de Ambientes Aquáticos Continentais (PEA) and the Universidade Tecnológica Federal do Paraná for logistical support. HFV thanks CAPES (Coordenação de Aperfeiçoamento de Pessoal de Nível Superior) for the scholarship. 


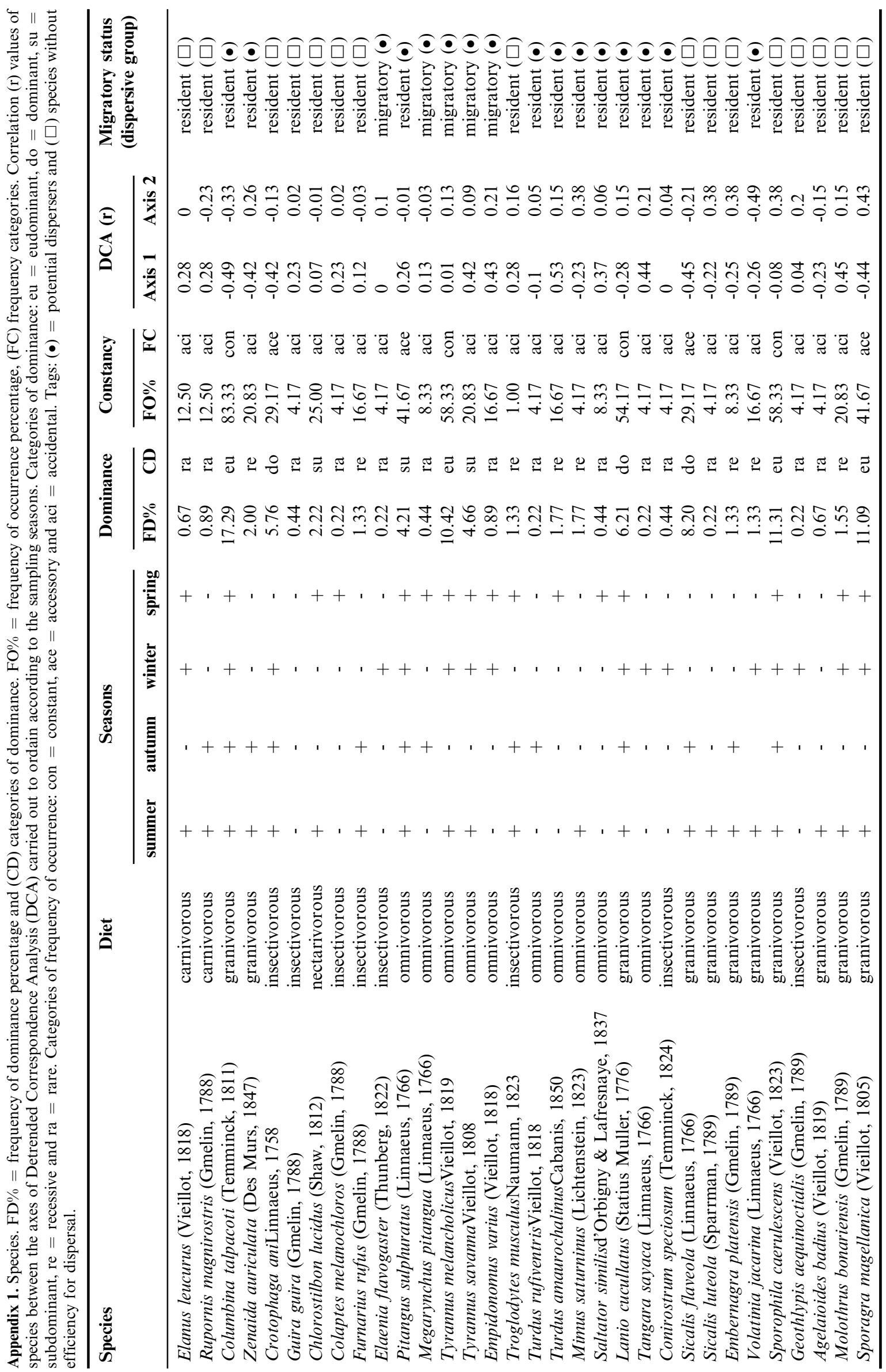




\section{References}

ALMEIDA, A., COUTO, H.T.Z. \& ALMEIDA, A.F. 2003. Diversidade beta de aves em hábitats secundários da Pré-Amazônia maranhense e interação com modelos nulos. Ararajuba 11(1):157-171.

ALVES, M.A.S. 2007. Sistemas de migrações de aves em ambientes terrestres no Brasil: exemplos, lacunas e propostas para o avanço do conhecimento. Revista Brasileira de Ornitologia 15(2):231-238.

ANDERSON, M.L. 1953. Spaced-group planting. Unasylva 7(2):1-15.

ARGEL-DE-OLIVIRA, M. M., CURI, N.A. \& PASSERINI, T. 1998. Alimentação de um filhote de Bem-te-vi, Pitangus sulphuratus (Linnaeus) (Passeriformes, Tyrannidae), em ambiente urbano. Revista Brasileira de Zoologia 15(4):1103-1109.

ATHIÊ, S. \& DIAS, M.M. 2012. Frugivoria por aves em um mosaico de Floresta Estacional Semidecidual e reflorestamento misto em Rio Claro, São Paulo, Brasil. Acta Botânica Brasilica 26(1):84-93, http://dx.doi.org/10.1590/S0102-33062012000100010

AZPIROZ, A.B., ISACCH, J.P., DIAS, R.A., DIGIACOMO, A.S., FONTANA, C.S. \& PALAREA C.M. 2012. Ecology and conservation of grassland birds in southeastern South America: a review. Journal of Field Ornithology 83(3):217-246, http://dx.doi.org/ 10.1111/j.1557-9263.2012.00372.x

BECHARA, F.C., FILHO, E.M.C., BARRETTO, K.D., GABRIEL, V.A., ANTUNES, A.Z. \& REIS, A. 2007. Unidades demonstrativas de restauração ecológica através de técnicas nucleadoras de biodiversidade. Revista Brasileira de Biociências 5(1):9-11.

BELTON, W. 1985. Birds of Rio Grande do Sul, Brazil, part 2. Formicariidae through Corvidae. Bulletin of the American Museum of Natural History 180: 01-242.

BENCKE, G.A. Lista de Referência das Aves do Rio Grande do Sul. Fundação Zoobotânica, Porto Alegre, 2001. 104 p.

BIBBY, C.J., BURGESS, N.D., HILL, D.A. \& MUSTOE, S.H. 2000. Bird Census Techniques. 2 ed. Academic Press, London.

BOCCHESE, R.A., OLIVEIRA, A.K.M., FAVERO, S., GARNÉS, S.J.S. \& LAURA, V.A. 2008. Chuva de sementes e estabelecimento de plântulas a partir da utilização de árvores isoladas e poleiros artificiais por aves dispersoras de sementes, em área de Cerrado, Mato Grosso do Sul, Brasil. Revista Brasileira de Ornitologia 16(3):207-213.

BUCHER, E.H. \& BOCCO, P.J. 2009. Reassessing the importance of granivorous pigeons as massive, long-distance seed dispersers. Ecology 90(8):2321-2327, http://dx.doi.org/10.1890/08-2077.1

BUZAS, M.A. \& HAYEK, L.A.C. 1998. SHE analysis for biofacies identification. The Journal of Foraminiferal Research 28(3): 233-239.

CAPLLONCH, P., ORTIZ, D. \& SORIA, K. 2008. Migración del Zorzal común Turdus amaurochalinus (Aves, Turdidae) en Argentina. Revista Brasileira de Ornitologia 16(1):12-22.

CARLO, T.A., AUKEMA, J.E. \& MORALES, J.M. 2007. PlantFrugivore Interactions as Spatially Explicit Networks: Integrating Frugivore Foraging with Fruiting Plant Spatial Patterns. In. Seed dispersal - theory and its application in a changing world (A.J. Dennis, E.W. Schupp, E.W. Green. \& D.A. Westcott, eds). Oxford shire, CAB International, Oxford, p. 360-390.

CARNEVALE, N.J. \& MONTAGNINI, F. 2002. Facilitating regeneration of secondary forests with the use of mixed and pure plantations of indigenous tree species. Forest Ecology and Management 163(1-3):217-227.

CAVES, E.M., JENNINGS, S.B.; HILLE, R., LAMBERS, J.H.R., TEWKSBURY, J.J. \& ROGERS H.S. 2013. Natural experiment demonstrates that bird loss leads to cessation of dispersal of native seeds from intact to degraded forests. PLoSONE 8(5):01-09, http:// dx.doi.org/10.1371/journal.pone.0065618

CÉSAR, R.G., VIANI, R.A.G., SILVA, M.C. \& BRANCALION, P.H.S. 2014. Does a native grass (Imperata brasiliensis Trin.) limit tropical forest restoration like an alien grass (Melinis minutioflora P. Beauv.)? Tropical Conservation Science 7(4):639-656.

CHESSER, R.T. 1994. Migration in South America: an overview of the austral system. Bird Conservation International 4(2-3):91-107, http://dx.doi.org/10.1017/S0959270900002690
CHRISTIANINI, A.V. \& GALETTI, M. 2007. Spatial variation in post-dispersal seed removal in an Atlantic forest: effects of habitat, location and guilds of seed predators. Acta Oecológica 32(3): 328-333, http://dx.doi.org/10.1016/j.actao.2007.06.004

COLWELL, R.K., MAO, C.X. \& CHANG, J. 2004. Interpolating, extrapolating, and comparing incidence-based species accumulation curves. Ecology 85(10):2717-2727, http://dx.doi.org/10.1890/ 03-0557

COMITE BRASILEIRO DE REGISTROS ORNITOLÓGICOS CBRO. 2014. Lista das aves do Brasil. http://www.cbro.org.br (last access 15/1/2014).

CORBIN, J.D. \& HOLL, K.D. 2012. Applied nucleation as a forest restoration strategy. Forest Ecology and Management 265(1):37-46, http://dx.doi.org/10.1016/j.foreco.2011.10.013

CUNHA, F.C.R. \& FONTENELLE, J.C.R. 2014. Registros de tumulto em aves no Brasil: uma revisão usando a plataforma Wikiaves. Atualidades Ornitológicas, 177:46-53.

DAJOZ, R. 1983. Ecologia geral. Vozes, Petrópolis.

FONSECA, F.Y. \& ANTUNES, A.Z. 2007. Frugivoria e predação de sementes por aves, Parque Estadual Alberto Löfgren. Revista do Instituto Florestal 9(2):81-91.

GABRIEL, V.A. \& PIZO, M.A. 2005. Foraging behavior of tyrant flycatchers (Aves, Tyrannidae) in Brazil. Revista Brasileira de Zoologia 22(4):1072-1077, http://dx.doi.org/10.1590/S0101-81752005000400036

GALETTI, M., LAPS, R. \& PIZO, M.A. 2000. Frugivory by Toucans (Ramphastidae) at Two Altitudes in the Atlantic Forest of Brazil. Biotropica 32(4):842-850, http://dx.doi.org/10.1111/j.1744-7429.2000. tb00622. $\mathrm{x}$

GASPERIN, G. \& PIZO, M.A. 2012. Passage time of seeds through the guts of frugivorous birds, a first assessment in Brazil. Revista Brasileira de Ornitologia 20(1):48-51.

GOMES, L.G.G., OOSTRA, V., NIJMAN, V., LEEF, A.M. \& KAPPELLE, M. 2008. Tolerance of frugivorous birds to habitat disturbance in a tropical cloud forest. Biological Conservation 141: 860-871, http://dx.doi.org/doi:10.1016/j.biocon.2008.01.007

GRAHAM, L.L.B. \& PAGE, S.E. 2012. Artificial Bird Perches for the Regeneration of Degraded Tropical Peat Swamp Forest: A Restoration Tool with Limited Potential. Restoration Ecology 20(5):631-637, http://dx.doi.org/doi:10.1111/j.1526-100X.2011.00805.x

GUEDES, M.C., MELO, V.A. \& GRIFFITH, J.J. 1997. Uso de poleiros artificiais e ilhas de vegetação por aves dispersoras de sementes. Ararajuba 5(2):229-232.

HALL, T.R., HOWARD, W.E. \& MARSH, R.E. 1981. Raptor Use of Artificial Perches. Wildlife Society Bulletin 9:296-298.

HAMMER, Ø., HARPER, D.A.T. \& RYAN, P.D. 2001. Paleontological statistics software package for education and data analysis. Palaeontologia Electronica 4:01-09.

HARTZ, S.M., PINHEIRO, G.C., MENDONÇA-LIMA, A.D. \& DUARTE, S. 2012. The potential role of Migratory Birds in the Expansion of Araucaria Forest. Natureza e Conservação 10(1):52-56, http://dx.doi.org/10.4322/natcon.2012.009

HOLL, K.D. 1998. Do Bird Perching Structures Elevate Seed Rain and Seedling Establishment in Abandoned Tropical Pasture? Restoration Ecology 6(3):253-261, http://dx.doi.org/10.1046/j.1526-100X.1998. 00638.x

HOLL, K.D., LOIK, M.E., LIN, E.H.V. \& SAMUELS, I.A. 2000. Tropical Montane Forest Restoration in Costa Rica: overcoming barriers to dispersal and establishment. Restoration Ecology 8(4): 339-349, http://dx.doi.org/10.1046/j.1526-100x.2000.80049.x

JORDANO, P.M., GALETTI, M., PIZO, M.A. \& SILVA, W.R. 2006. Ligando frugivoria e dispersão de sementes à biologia da conservação. In Biologia da conservação: essências (C.F. Duarte, H.G. Bergallo, M.A.S. Alves. \& M. Van Sluys eds). Editorial Rima, São Paulo, p. 411-436.

JOSEPH, L. 1996. Preliminary climatic overview of migration patterns in South America austral migrant passerines. Ecotropica 2:185-193.

KREBS, C.J. 1999. Ecological Methodology. Harper and Row, New York., http://dx.doi.org/10.2307/3546582 
LIEBSCH, D. \& MIKICH, S.B. 2009. Fenologia reprodutiva de espécies vegetais da Floresta Ombrófila Mista do Paraná, Brasil. Brazilian Journal of Botany 32(2):375-391, http://dx.doi.org/10.1590/ S0100-84042009000200016

LINDELL, C.A. \& THURSTON, G.M. 2013. Bird pollinator visitation is equivalent in island and plantation planting designs in tropical forest restoration sites. Sustainability 5(3):1177-1187, http:// dx.doi.org/10.3390/su5031177

LINSDALE, J.M. \& RODGERS, T.M. 1937. Frequency of occurrence of birds in Alum Rock Park, Santa Clara County, California. 39(3): 108-111, http://dx.doi.org/10.2307/1363741

MAACK, R. 2002. Geografia física do Estado do Paraná. Imprensa Oficial, Curitiba.

MARINI, M.Â., LOBO, Y., LOPES, L.E., FRANÇA, L.F. \& PAIVA, L.V. 2009. Breeding biology of Tyrannus savana (Aves, Tyrannidae) in cerrado of Central Brazil. Biota Neotropica 9(1):55-63, http://dx.doi.org/10.1590/S1676-06032009000100007

MARTINS-OLIVEIRA, L., LEAL-MARQUES, R., NUNES, C.H., FRANCHIN, A.G. \& MARÇAL-JÚNIOR, O. 2012. Forrageamento de Pitangus sulphuratus e de Tyrannus melancholicus (Aves: Tyrannidae) em hábitats urbanos. Bioscience Journal 28(6):1038-1050.

McCUNE, B. \& MEFFORD, M.J. PC-ORD. 2011. Multivariate Analysis of Ecological Data. Oregon: MjM Software.

MELO, A.S. 2008. O que ganhamos "confundindo" riqueza de espécies e equabilidade em um índice de diversidade? Biota Neotrópica 8(3): 21-27, http://dx.doi.org/10.1590/S1676-06032008000300001

MIKICH, S.B. \& SILVA, S.M. 2001. Composição florística e fenologia das espécies zoocóricas de remanescentes de floresta estacional semidecidual no centro-oeste do Paraná, Brasil. Acta Botânica Brasílica 15(1): 89-113, http://dx.doi.org/10.1590/S0102-33062001000100010

MORRISON E.B. \& LINDELL, C.A. 2012. Birds and bats reduce insect biomass and leaf damage in tropical forest restoration sites. Ecological Applications 22(5):1526-1534.

PALISSA, A.E. \& WIEDENROTH, M. \& KLIMT, K. 1977. Anleitung zum ökologischen Geländepraktikum. Wissenschaftliches Zentrum der Pädagogischen Hochschule, Potsdam.

PIAS, K.E. \& WELCH, Z.C. \& KITCHENS, W.M. 2012. An artificial perch to help snail kites handle an exotic apple snail. Waterbirds 35(2): 347-351, http://dx.doi.org/10.1675/063.035.0217

PILLATT, N., PILLATT, N., FRANCO, E.T.H.F. \& COELHO, G.C. 2010. Dry artificial perches and the seed rain in a subtropical riparian forest. Brazilian Journal of Biosciences 8(3):246-252.

PINESCHI, R.B. 1990. Aves como dispersoras de sete espécies de Rapanea (Myrsinaceae) no maciço de Itatiaia, estados do Rio de Janeiro e Minas Gerais. Ararajuba 1:73-78.

PIZO, M.A. 2004. Frugivory and habitat use by fruit-eating birds in a fragmented landscape of southeast Brazil. Ornitologia Neotropical 15:117-126.

PIZO, M.A. 2007. Frugivory by birds in degraded areas of Brazil. In. Seed dispersal - theory and its application in a changing world (A.J. Dennis., E.W. Schupp., E.W. Green. \& D.A. Westcott, eds). Oxford shire, CAB International, Oxford, p. 615-627.

QUINN, G.P. \& KEOUGH, M.J. 2002. Experimental Design and Data Analysis for Biologists. Cambridge University Press, New York.

REIS, A., BECHARA, F.C. \& TRES, D.R. 2010. Nucleation in tropical ecological restoration. Scientia Agricola 67(2):244-250.

REY-BENAYAS, J.M., BULLOCK, J.M. \& NEWTON, A.C. 2008. Creating woodland islets to reconcile ecological restoration, conservation, and agricultural land use. Frontiers in Ecology and the Environment 6(6): 329-336, http://dx.doi.org/10.1890/070057

RIDGELY, R.S. \& TUDOR, G. 2001. The Birds of South America. Vol II. The Oscine Passerines. University of Texas Press, Austin.

RODRIGUES, R.R., GANDOLFI, S., NAVE, A.G., ARONSON, J., BARRETO, T.E., VIDAL, C.Y. \& BRANCALION, P.H.S. 2011. Large-scale ecological restoration of high-diversity tropical forests in SE Brazil. Forest Ecology and Management 261(10):1605-1613, http://dx.doi.org/10.1016/j.foreco.2010.07.005

SEKERCIOGLU, C.H. 2006. Increasing awareness of avian ecological function. Trends in Ecology \& Evolution 21(8):464-71, http://dx.doi.org/ 10.1016/j.tree.2006.05.007

SHIELS, A.B. \& WALKER, L.R. 2003. Birds Perches Increase Forest Seeds on Puerto Rican Landslides. Restoration Ecology 11(4):457-465, http://dx.doi.org/10.1046/j.1526-100X.2003.rec0269.x

SHONO, K., CADAWENG, E.A., DURST, P.B., 2007. Applications of assisted natural regeneration to restore degraded tropical forestlands. Restoration Ecology 15:620-626, http://dx.doi.org/10.1111/ j.1526-100X.2007.00274.x

SICK, H. 1997. Ornitologia brasileira. Nova Fronteira, Rio de Janeiro. SILVA, W.R., PIZO, M.A.; GABRIEL, V.A. 2010. Avifauna como promotora da restauração ecológica. In Ornitologia e Conservação: Ciência Aplicada, Técnicas de Pesquisa e Levantamento (S. VON MATTER, F.C. STRAUBE, I. ACCOERDI, V.E. PIACENTINI, \& J.F. CÂNDIDO-JR eds). Technical Books Editora, Rio de Janeiro, p. 507-516.

STAGGMEIER, V.G. \& GALETTI, M. 2007. Impacto humano afeta negativamente a dispersão de sementes de frutos ornitocóricos: uma perspectiva global. Revista Brasileira de Ornitologia 15(2):281-287.

STRONG, A.M., SHERRY, T.W. \& HOLMES, R.T. 2000. Bird predation on herbivorous insects: indirect effects on sugar maple saplings. Oecologia 125(3):370-379, http://dx.doi.org/10.1007/s004420000467

STOTZ, D.F., FITZPATRICK, F.W. \& PARKER III, T.A. \& MOSKOVITS D.K. 1996. Neotropical birds: ecology and conservation. University of Chicago Press, Chicago.

TOMAZ, V.C. \& ALVES, M.A.S. 2009. Comportamento territorial em aves: regulação populacional, custos e benefícios. Oecologia Brasiliensis 13(1):132-140.

VICENTE, R., MARTINS, R., ZOCCHE, J.J. \& HARTER-MARQUES, B. 2010. Seed dispersal by birds on artificial perches in reclaimed areas after surface coal mining in Siderópolis municipality, Santa Catarina State, Brazil. Revista Brasileira de Biociências 8(1):14-23.

VIEIRA, I.C.G. \& SILVA, J.M.C. 1997. Phenology, fruit set and dispersal of Cordia multispicata Cham., an important weed shrub of abandoned pastures in eastern Amazonia. Revista Brasileira de Botânica 20(1): 51-56, http://dx.doi.org/10.1590/S0100-84041997000100005

VOGEL, H.F., ZAWADZKI, C.H. \& METRI, R. 2012. Occurrence of thrushes in an urban fragment of Araucaria forest in southern Brazil. Biota Neotrópica 12(4):241-247, http://dx.doi.org/10.1590/ S1676-06032012000400024

WUNDERLE JR., J.M., 1997. The role of animal seed dispersal in accelerating native forest regeneration on degraded tropical lands. Forest Ecology and Management 99:223-235, http://dx.doi.org/ 10.1016/S0378-1127(97)00208-9

ZANINI, L. \& GANADE, G. 2005. Restoration of Araucaria forest: the role of perches pioneer vegetation, and soil fertility. Restoration Ecology 13(3):507-514, http://dx.doi.org/10.1111/j.1526-100X.2005. 00063.x 